Check for updates

The BMJ

Cite this as: $B M J 2020 ; 369: m 2486$ http://dx.doi.org/10.1136/bmi.m2486 Published: 22 June 2020

\section{Covid-19: Local health teams trace eight times more contacts than national service}

\author{
Elisabeth Mahase
}

Local health protection teams have traced nearly eight times more contacts (77 642) than the national call centres and online service (9997), latest figures show. ${ }^{1}$

The NHS Test and Trace system brings together the local health protection teams that handle complex cases, and the national call centre and online system-run by two private companies, Serco and Sitel.

The contracts awarded to operate test and trace are reportedly worth £108m (€120m; \$134m) in total, ${ }^{2}$ and some experts have said this money would have been better spent on resourcing and funding local public health teams, who were already in place and could have led the initiative.

The system began on 28 May 2020 and until 10 June it had attempted to contact 14045 covid-19 positive people, of whom $72.6 \%$ (10 192) were reached and asked to provide details of their recent close contacts. From this, 96746 people were identified as close contacts and 87639 were reached (90.6\%).

Between 31 May and 13 June, however, the Office for National Statistics (ONS) reported that 33 ooo people tested positive for covid-19 in England. ${ }^{3}$ This suggests that potentially half of the cases are being missed by the contact tracing service.

Additionally, when the numbers of contacts identified by the system are broken down by who handled them, significantly more came from local health teams than the national centres and website. According to the latest report (18 June), of 87639 close contacts that were reached, only 9997 were non-complex cases handled by the national teams. This means the remaining 77642 were complex cases handled by local teams.

In a statement, the Independent Scientific Advisory Group for Emergencies (iSAGE) said, "This raises serious questions about the efficiency and value for money of the contracts and highlights the vital role being played by the public health teams in track and trace."

The group also pointed to "extensive data gaps" in the report. "This means we cannot tell how well the system is working. The actual number of daily and weekly cases in the community is unknown because testing has been chaotic and haphazard, and the methodology is now being revised. Because of this we don't know how many cases have been missed and have not been transferred for contact tracing. ONS survey data suggests there are many missing cases.”
ISAGE also noted that the report doesn't show how many contacts are isolating, or how many go on to become symptomatic and test positive.

“The government's own Scientific Advisory Group for Emergencies advises that $80 \%$ of contacts of all new symptomatic covid-19 cases need to self-isolate. This goal is far from being reached," iSAGE said.

Allyson Pollock, co-director of the Newcastle University Centre for Excellence in Regulatory Science and iSAGE committee member, told The BMJ, "It is extraordinary that instead of using the tried and tested public health system and building that up with resources, the government has instead put in a centralised, privatised system that has not been shown to work or been evaluated.

"If they had diverted all the money they spent on enabling public health and local authorities and Public Health England, we would have had contact tracing off the ground much sooner and we may have saved lives."

The figures came as a survey of 1022 adults in the UK-commissioned by We Own It, which campaigns against the privatisation of public services-found that $46 \%$ said they did not have confidence in Serco to manage the track and tracing programme effectively. Only $27 \%$ said they did have confidence, while $28 \%$ said they didn't know.

Department of Health and Social Care. NHS Test and Trace. Experimenta statistics: weekly NHS Test and Trace bulletin, England: 28 May-10 June 2020. https://assets.publishing.service.gov.uk/government/uploads/system/uploads/attachment_data/file/893172/test_and_trace_bulletin_week_2_28_may_to_10_june.pdf.

2 Mueller B, Bradley J. England's 'world beating' system to track the virus is anything but. New York Times. 17 June 2020. www.ny-

times.com/2020/06/17/world/europe/uk-contact-tracing-coronavirus.html.

3 ONS. Coronavirus: (covid-19) infection survey. 18 June 2020. www.ons.gov.uk/peoplepopulationandcommunity/healthandsocialcare/conditionsanddiseases/datasets/coronaviruscovid19infectionsurveydata.

This article is made freely available for use in accordance with BMJ's website terms and conditions for the duration of the covid-19 pandemic or until otherwise determined by BMJ. You may use, download and print the article for any lawful, non-commercial purpose (including text and data mining) provided that all copyright notices and trade marks are retained. 